\title{
Morphological and physical properties in diagnostics of urban soils: case study from Moscow, Russia
}

\author{
Tatiana Prokof'eva ${ }^{*}$, Aminat Umarova ${ }^{2}$, Galina Bykova ${ }^{2}$, Maria Suslenkova ${ }^{2}$, Zakhar Ezhelev², \\ Anna Kokoreva ${ }^{2}$, Anastasia Gasina ${ }^{2}$, Irina Martynenko ${ }^{1}$ \\ ${ }^{1}$ Lomonosov Moscow State University, Faculty of Soil Science, Department of Soil Geography, Leninskie gory 1-12, 119991, Moscow, Russia \\ ${ }^{2}$ Lomonosov Moscow State University, Faculty of Soil Science, Department of Soil Physics, Leninskie gory 1-12, 119991, Moscow, Russia \\ * Ph Dr T.V. Prokof'eva, tatianaprokofieva@yandex.ru, ORCID iD: https://orcid.org/0000-0002-7729-2684
}

Received: 25.06.2020

Accepted: 11.12 .2020

Associated editor: Ł. Uzarowicz

\section{Keywords}

Urbic Technosols

Diagnostic horizons

Bulk density

Saturated hydraulic conductivity

Penetration resistance

\begin{abstract}
The whole complex of soil properties formed during a long process of evolution is used in soil diagnostics. Following the genetic approach, which proposes the designation of a specific diagnostic horizon that represents stages of specific urban synlitogenic soil formation on thick human-made deposits, we face the problem of separating truly soil horizons from layers of man-made deposits, as both contain significant amounts of artefacts. In addition, they have similar chemical and physical-chemical properties corresponding to general geochemical characteristics of the urban environment. A comparative analysis of morphological and physical characteristics was conducted for several soils of loamy texture within the city of Moscow, Russia. Their morphological descriptions were accompanied by determinations of bulk density, saturated hydraulic conductivity and penetration resistance. For the analysis of morphological and physical properties, soil diagnostic horizons were arranged in four groups (synlithogenic urbic humus horizons, postlithogenic humus horizons, technogenic layers and horizons inherited from natural texturally-differentiated soils). Most of the studied soil profiles had significant contents of solid inclusions (domestic waste and building rubble) that allowed us to define them as Urbic Technosols, according to the WRB soil classification system. It was confirmed that, in addition to specific chemical and morphological properties, man-made urban soils had specific physical characteristics. The abundance of inclusions of building rubble and domestic waste had a strong influence on physical properties such as bulk density and saturated hydraulic conductivity. Heterogeneous distribution of such properties within urban soil profiles could be considered as their characteristic feature. As a result, this study confirmed the identification of certain diagnostic horizons by establishing statistically significant differences in their bulk densities and saturated hydraulic conductivity. Penetration resistance was shown to be a less informative parameter in this study. We believe that more data on physical properties of different types of horizons should be accumulated for making it possible to establish typical values of physical characteristics of such horizons.
\end{abstract}

\section{Introduction}

Physical properties are very important characteristics because they predetermine plant growth conditions and thermohydrological soil regimes and serve as essential parameters for soil assessments and prognoses associated with different aspects of soil use. Basic physical characteristics such as texture class (particle-size distribution), degree of compaction (density), porosity and structure are specified at first stages of soil profile investigation, i.e., in the course of morphological description. However, quantitative parameters of physical properties are only infrequently used as soil diagnostic tools, except for particle-size distribution that predetermines soil texture class, which is a diagnostic tool and a part of a complete name of every soil in many classification systems. Soil physical properties accompany morphological characteristics and supplement them with quantitative data that are almost absent in soil morphological descriptions. During a morphological description of soil, conventional methods are used to describe physical characteristics including texture, structure, density, etc. Then, during soil analytical studies, we obtain quantitative data, which can often help us to refine diagnostics of certain horizons.

Physical properties of urban soils have attracted attention of researchers from the very beginning of studies on such soils. According to many studies (Short et al., 1986; Mullins, 1991; Craul, 1992; Stroganova et al., 1998), physical characteristics of 
urban soils are deteriorated as a result of compaction, decreases in porosity and aeration, either too low or to high infiltration rates, etc. One of the main features of urban soils is a high spatial variability of their properties within a small surface area (Blanchart et al., 2018; Nero and Anning, 2018). The absolute majority of human-affected soils in cities suffer from compaction. Their upper layers are compacted due mechanical impacts and lower layers - due to pressures of various constructions (Lehmann and Stahr, 2007; Yang and Zhang, 2011; Ferreira et al., 2018).

Processes of urban soil development are associated with changes in their properties. For example, there is a study by Scharenbroch and co-authors (Scharenbroch et al., 2005) conducted on soils within areas of old (more than 64 years) and new (less than 20 years) residential buildings in two cities in the USA: Moscow (Indiana state) and Pullman (Washington state). The study has shown that soils had the highest density $\left(1.73 \mathrm{~g} \mathrm{~cm}^{-3}\right)$ within new residential sites, a lower density $\left(1.41 \mathrm{~g} \mathrm{~cm}^{-3}\right)$ within old residential sites and the lowest density $\left(1.39 \mathrm{~g} \mathrm{~cm}^{-3}\right)$ within streets and parks, which led the authors to a conclusion that physical properties of soils of old residential sites partly recover from intense impaction over time. However, this can otherwise be interpreted as a result of a natural diversity of soils.

Saturated hydraulic conductivity $\left(\mathrm{K}_{\mathrm{s}}\right)$ is also a very important characteristic of soils (Jackson et al., 2014). Low hydraulic conductivity is caused by high degrees of soil compaction and negatively affects the environment of a city due to a significant runoff from soil surface to rivers, lakes and ponds, which leads to deterioration of their water quality. High saturated hydraulic conductivity is indicative of a probable shortage of water. According to results of the study (Yang and Zhang, 2011) on Nanjing city soils under different types of land use (a residential area, a park, vegetation planted on a roadside and a campus area), the authors report a high variability of infiltration rates in Nanjing city soils, which is explained by differences in densities (from 1.19 to $1.65 \mathrm{~g} \mathrm{~cm}^{-3}$ ), total porosity (from 39 to 55\%) and aeration porosity (from 0.7 to $8 \%$ ) of soil samples. A decrease in saturated hydraulic conductivity with an increase in density and decrease in porosity has been also reported in Moscow city soils (Stroganova et al., 1998). Soils of urban forests are characterized by different infiltration rates depending on intensities of the recreational land use, i.e., lower infiltration rates tend to occur within most trampled areas and higher infiltration rates - within least trampled areas, e.g., along motorways. A generally high variability of infiltration rates in such soils is, in our opinion, predominantly associated with the spatial heterogeneity of soil density predetermined by the type of anthropogenic impact. In addition, infiltration rates depend on types of vegetation and root systems (Wang et al., 2018). Some authors (Dornauf and Burghardt, 2000) believe that high infiltration rates are predetermined by a presence of biopores that are capable of providing a transitory water percolation, irrespective of the texture of soil horizons.

Soils of large cities are often significantly transformed under the impact of human activities. Specific properties of soils typical for a man-made environment are used for diagnostics in the Reference Soil Group of Technosols in the international soil classification system (IUSS Working Group WRB, 2015). Diagnostics of Technosols is mainly based on characteristics of soil par- ent materials including those, which directly or indirectly correspond to physical properties. Primarily, such characteristics include the quantity of solid-phase artefacts, the type of those artefacts (construction waste, industrial waste, domestic waste, etc.) and the presence of impermeable layers in the middle or at the surface of soil profiles.

A soil genetic approach can also be applied to the systematics of urban soils (Stroganova et al., 1998; Prokofyeva et al., 2011; Prokof'eva et al., 2013; Prokof'eva et al., 2014). This approach implies that pedogenic humus-accumulative horizons should be separated from layers of technogenic materials non-affected or weakly affected by pedogenesis. Hence, two varieties of pedogenic humus-accumulative horizons and three varieties of layers of technogenic materials serving as substrates for subsequent pedogenesis should be distinguished for describing technogenic soils of urban areas. Pedogenic horizons are defined as follows: 1. Urbic (UR) horizon - synlithogenic (i.e., with a simultaneous development of pedogenesis and lithogenesis), occurs only in urban soils, where it is gradually formed in the course of a surface deposition of various substrates in various quantities; 2. Postlithogenic humus (AY, AU) horizons - develop on either technogenic or natural substrates, in the absence of active additions of materials onto the soil surface. Technogenic layers are defined as follows: 1 . True technogenic layer (TCH) - consists of mineral substrates that have been either mixed, translocated or contaminated and contain artefacts; 2 . Filled compost-mineral layer (RAT) - consists of either compost, peaty compost or humified material applied to soil surface as a reclamation measure and almost non-altered by pedogenesis in situ, with widely varied properties predetermined by the technology used for its creation; 3. Filled peat layer (RT) - consists mostly of peat, which is used for soil reclamation in northern regions of the Russian Federation.

The use of the above-described approach is problematic in terms of separating modern pedogenic horizons from technogenic ground layers, because they both contain significant amounts of anthropogenic inclusions (artefacts). In addition, they have similar chemical and physicochemical properties, which are associated with general geochemical characteristics of urban environments and soils (Stroganova et al., 1998; Lehmann and Stahr, 2007; Prokofyeva et al., 2011; Hulisz et al., 2018). Urban soil horizons are usually characterized by a presence of carbonate inclusions, neutral or alkaline $\mathrm{pH}$ and accumulations of organic carbon and phosphorus. However, significantly different values of physical characteristics (in particular, bulk density and penetration resistance) have been identified in pedogenic horizons and technogenic (TCH) layers as a result of our previous assessment of mean parameter values that characterize each type of urban soil horizons (Prokofyeva et al., 2011).

Parameters that characterize soil physical properties can potentially serve as additional quantitative criteria for urban soil diagnostics. The aim of this study was to confirm the actual possibility for using physical characteristics as diagnostic tools for urban soil horizons by means of conducting a comparative analysis of physical characteristics and morphological features used for soil horizon identification in our field studies on several Urbic Technosols within the city of Moscow. 


\section{Materials and methods}

\subsection{Study area and materials}

The study was conducted in the city of Moscow (Russia) located within the southern taiga subzone, with a moderately continental climate, a percolative soil water regime and a seasonal freezing of soils. There is a great diversity of native soils formed within the territory of Moscow, which corresponds to a conjunction zone of several landscape types (Nizovt- sev, 2004). Soil profiles described in this paper were formed within areas of moraine plains. Albic Retisols (Siltic) and soils formed by human influence on their basis are known as most widespread native soils of moraine plains within the Moscow region (Stroganova et al., 1998; Prokof'eva and Martynenko, 2017).

Six different profiles of loamy-textured urban soils were studied within the city of Moscow, mainly within the Lomonosov Moscow State University (LMSU) campus in Leninskie (Vorob’evy) Gory (Table 1, Fig. 1).

Table 1

Comparative characteristics of the studied soil profiles

\begin{tabular}{|c|c|c|c|c|c|}
\hline $\begin{array}{l}\text { Pit } \\
\text { № } \\
\end{array}$ & $\begin{array}{l}\text { Names according to Prokof'eva et al. } \\
\text { (2014) and Shishov et al. (2004) }\end{array}$ & $\begin{array}{l}\text { Names according } \\
\text { to WRB (2015) }\end{array}$ & $\begin{array}{l}\text { Location } \\
\text { (coordinates) }\end{array}$ & Degree of human impact & Land use \\
\hline 1 & $\begin{array}{l}\text { Soddy-podzolic, surface-turbated, } \\
\text { thin, deeply bleached, medium } \\
\text { loam*, on mantle loams }\end{array}$ & $\begin{array}{l}\text { Albic Glossic Retisol } \\
\text { (Siltic, Turbic, } \\
\text { Prototechnic) }\end{array}$ & $\begin{array}{l}\text { LMSU campus } \\
55^{\circ} 42^{\prime} 21^{\prime \prime} \mathrm{N} \\
37^{\circ} 32^{\prime} 20^{\prime \prime} \mathrm{N}\end{array}$ & $\begin{array}{l}\text { Weakly changed natural soil } \\
\text { in the city }\end{array}$ & $\begin{array}{l}\text { Park with lime trees, } \\
70 \text { years in the city }\end{array}$ \\
\hline 2 & $\begin{array}{l}\text { Urbostratozem, thin, deeply } \\
\text { weakly gleyed, medium loam, on } \\
\text { technogenic deposits underlain by } \\
\text { mantle loams }\end{array}$ & $\begin{array}{l}\text { Urbic Technosol (Siltic, } \\
\text { Umbric, Stagnic) } \\
\text { underlayed by mantle } \\
\text { loams }\end{array}$ & $\begin{array}{l}\text { Meteorological } \\
\text { Observatory, LMSU } \\
\text { campus (55²'24” N, } \\
\left.37^{\circ} 31^{\prime} 18^{\prime \prime} \mathrm{E}\right)\end{array}$ & $\begin{array}{l}\text { Profile was deeply } \\
\text { transformed during the LMSU } \\
\text { construction, with 56-cm-thick } \\
\text { layer of technogenic materials }\end{array}$ & $\begin{array}{l}\text { Lawn, } 70 \text { years in the } \\
\text { city }\end{array}$ \\
\hline 3 & $\begin{array}{l}\text { Urbostratozem, thick, calcareous, } \\
\text { loamy sand - light loam**, on cultur- } \\
\text { al layer underlain by arable soddy- } \\
\text { podzolic calcareous clay loam soil }\end{array}$ & $\begin{array}{l}\text { Urbic Technosol } \\
\text { (Archaic, Calcic, Hortic, } \\
\text { Humic, Loamic) }\end{array}$ & $\begin{array}{l}\text { Mansion in the city } \\
\text { center, Mal. Znamen- } \\
\text { skii per. }\left(55^{\circ} 44^{\prime} 52^{\prime \prime} \mathrm{N} \text {, }\right. \\
\left.37^{\circ} 36^{\prime} 15^{\prime} \mathrm{E}\right)\end{array}$ & $\begin{array}{l}\text { Profile was deeply trans- } \\
\text { formed. Layer of technogenic } \\
\text { materials } 190 \mathrm{~cm} \text { thick, under- } \\
\text { lain by a plough layer }\end{array}$ & $\begin{array}{l}\text { Courtyard in a residen- } \\
\text { tial area, } 600 \text { years in } \\
\text { the city, } 300 \text { years with } \\
\text { stone buildings }\end{array}$ \\
\hline 4 & $\begin{array}{l}\text { Technogenic Agrozem, light loam, } \\
\text { on technogenic deposits }\end{array}$ & Phaeozem (Aric, Siltic) & $\begin{array}{l}\text { Botanical Garden, } \\
\text { LMSU campus } \\
\left(55^{\circ} 42^{\prime} 18^{\prime \prime} \mathrm{N}\right. \\
37^{\circ} 31^{\prime} 37^{\prime \prime} \text { E) }\end{array}$ & $\begin{array}{l}\text { Reclaimed soil, regularly } \\
\text { fertilized, on turbated } \\
\text { grounds. Layer of technogenic } \\
\text { materials }>60 \mathrm{~cm} \text { thick. }\end{array}$ & $\begin{array}{l}\text { Flower bed, } 70 \text { years } \\
\text { in the city }\end{array}$ \\
\hline 5 & $\begin{array}{l}\text { Gray-humus, calcareous, thin, light } \\
\text { loam, on technogenic deposits }\end{array}$ & $\begin{array}{l}\text { Urbic Technosol (Calcic, } \\
\text { Hyperartefactic, } \\
\text { Loamic) }\end{array}$ & $\begin{array}{l}\text { LMSU campus } \\
\left(55^{\circ} 42^{\prime} 25^{\prime \prime} \mathrm{N} \text {, }\right. \\
\left.37^{\circ} 31^{\prime} 24^{\prime \prime} \mathrm{E}\right)\end{array}$ & $\begin{array}{l}\text { Humus-accumulative soil } \\
\text { formed on technogenic } \\
\text { materials }>55 \mathrm{~cm} \text { thick. }\end{array}$ & $\begin{array}{l}\text { Trees planted in the } \\
\text { inner yard of a building, } \\
70 \text { years in the city }\end{array}$ \\
\hline 6 & $\begin{array}{l}\text { Gray-humus, calcareous, shallow, } \\
\text { light loam, on technogenic deposits }\end{array}$ & $\begin{array}{l}\text { Urbic Technosol (Calcic, } \\
\text { Hyperartefactic, } \\
\text { Loamic) }\end{array}$ & $\begin{array}{l}\text { LMSU campus } \\
\left(55^{\circ} 42^{\prime} 25^{\prime \prime} \mathrm{N},\right. \\
\left.37^{\circ} 31^{\prime} 24^{\prime} \mathrm{E}\right)\end{array}$ & $\begin{array}{l}\text { Humus-accumulative soil } \\
\text { formed on technogenic } \\
\text { materials }>50 \mathrm{~cm} \text { thick. }\end{array}$ & $\begin{array}{l}\text { Lawn in the inner yard } \\
\text { of a building, } 70 \text { years } \\
\text { in the city }\end{array}$ \\
\hline
\end{tabular}

*Medium loams include texture classes of sandy clay loam and clay loam.

**Light loams include texture classes of sandy loam and sandy silt loam.

Fig. 1. Soils profiles with horizons: pit 1. Albic Glossic Retisol; pit 2. Urbic Technosol underlain by mantle loams; pit 3. Deep Urbic Technosol underlain by cultural layers; pit 6 Urbic Technosol on technogenic sediments. Horizons: AU - dark colored postlithogenic humus horizon; AY - grey colored postlithogenic humus horizon; TUR - turbated; UR - urbic; TCH - technogenic; EL, BEL, BT and BCg - inherited horizons of natural soils; $\mathrm{P}$-plough layer

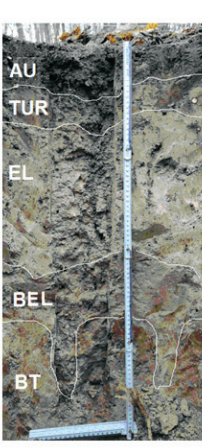

Pit 1

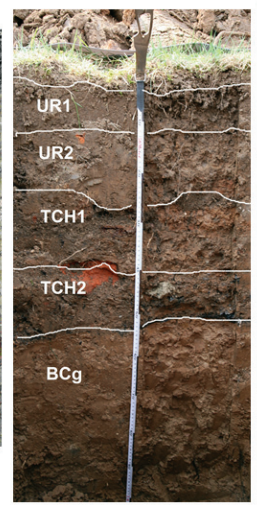

Pit 2

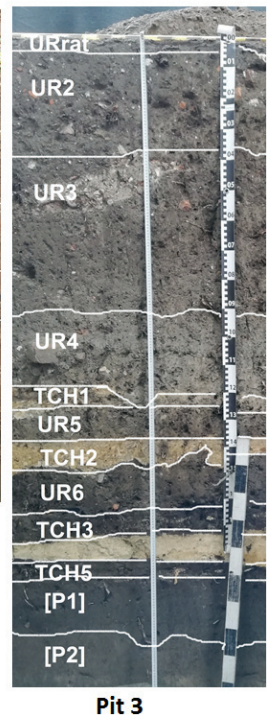

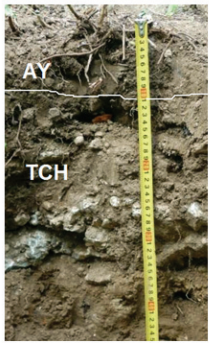

Pit 6 
Taxonomic definitions of the studied soil profiles (Table 1) are based on the Classification and Diagnostic System of Soils of Russia (Shishov et al., 2004) supplemented with our recently proposed terms for urban soil description (Prokof'eva et al., 2014). All soil names are correlated with the World Reference Base for Soil Resources (2015). Soil descriptions are correlated with the Guidelines for Soil Description (2006).

\subsection{Methods of soil analyses}

Bulk density $\left(\rho_{b}\right)$ of soils was determined with the use of cylinder cores (GOST 5180-84, McKenzie et al., 2002). Saturated hydraulic conductivity was determined by the method of tubes with a constant pressure, with a subsequent approximation using Horton's equation (Shein and Karapachevskii, 2007; Beven and Robert, 2004). Penetration resistance was measured with the use of N.A. Kachinskii's modification of micro-penetrometer with a cone-shaped plunger driven into the ground (Shein and Karapachevskii, 2007).

\subsection{Statistical analyses}

To enable a combined analysis of morphological and physical properties of the studied soils, all their horizons were subdivided on the basis of their morpho-genetic characteristics into the following four groups: (1) technogenic (TCH) grounds of massive consistency; (2) urbic (UR) horizons with sedimentogenetic features represented by fine stratification; (3) postlithogenic humus (AY, AU) horizons; (4) inherited (EL, BEL, BT, BC) horizons of native texturally-differentiated soils (Albic Retisols). Statistical parameters (mean, median, quarter and dispersion) of physical properties were calculated for each group. Statistical sample sizes (number of measurements) for different properties and horizons are presented in Table 2.

\section{Results}

Relationships between morphological and physical characteristics were identified in soils of similar texture (loams), because the particle-size distribution is known to have highly significant influence on other physical properties as well as all morphological and chemical properties. It should be noted that increased percentages of coarse fractions (sand) in upper horizons are typically found in loamy soils of Moscow (Stroganova et al., 1998)

Table 2

Statistical sample sizes for analyzed physical characteristics of soil horizons

\begin{tabular}{|c|c|c|c|c|}
\hline \multirow[t]{2}{*}{ Properties } & \multicolumn{4}{|c|}{ Horizons } \\
\hline & $\mathrm{TCH}$ & UR & $\mathrm{AY}, \mathrm{AU}$ & Inherited horizons of natural soils \\
\hline Bulk density & 27 & 24 & 10 & 15 \\
\hline Saturated hydraulic conductivity & 21 & 24 & 30 & 15 \\
\hline Penetration resistance & 39 & 68 & 10 & 50 \\
\hline
\end{tabular}

\subsection{Morphological features}

The six pits (see Table 1) analyzed in the present study include three deep profiles (pits 1, 2 and 3), which represent consecutive stages of the human-induced transformation of native texturally differentiated soils (Albic Retisols) and the formation of urban cultural layers, and three shallow profiles (pits 4, 5 and 6), which represent young soils formed on technogenic substrates over a period of 60-70 years since building of the LMSU campus. Detailed descriptions of the studied pits are presented below.

Pit 1. Located within a flat area under a plantation of smallleaved lime (Tilia cordata). Fallen leaves and twigs are removed from the site in spring. Soil profile is described in Table 3. Judging from the morphological description, this soil was defined as surface-turbated soddy-podzolic (Albic Retisol). Its upper horizons were turbated (mixed) during construction works 60-70 years ago or earlier by ploughing and subsequently a postlithogenic humus horizon has developed at the surface. Structure of the horizons is inherited from the natural soil.

Pit 2. Located within a flat area, at the distance of $20 \mathrm{~m}$ from the Meteorological Observatory building, at the edge of a plot for a long-term monitoring of soil-ground temperatures. Grassy vegetation has a projective cover of $98 \%$. Dry leaves and twigs from nearby trees are regularly removed from the plot area. Soil profile is described in Table 4.

This synlithogenic soil was defined as urbostratozem underlain by mantle loam (Urbic Technosol). It had well-structured synlithogenic humus horizons (UR), which were underlain by structureless technogenic horizons (TCH), with the natural transitional horizon of native soil at the bottom of the profile.

Pit 3. Corresponds to an archaeological excavation on the territory owned by the Pushkin State Museum of Fine Arts in the city center, within the courtyard of the $18^{\text {th }}$ century mansion (which belonged to Golytsyn-Vyazemskii-Dolgorukov princes) surrounded by the late $19^{\text {th }}$ century openwork forged fence. Vegetation near the pit was represented by few broad-leaved trees and almost no grass. Soil profile is described in Table 5. The upper part of this urbostratozem (Urbic Technosol) consisted of several UR humus horizons with well-developed structure. Its horizontal orientation together with almost smooth boundaries between horizons were indicative of synlithogenic genesis of these horizons and a whole profile. Deeper, urbic horizons alternated with technogenic layers consisting of carbonate material. From the depth of $190 \mathrm{~cm}$, there was a buried native soil (texturally-differentiated, Albic Retisol). 
Table 3

The morphological description of Albic Retisol. Pit 1

\begin{tabular}{|c|c|c|c|}
\hline $\begin{array}{l}\text { Horizon } \\
\text { (Russian } \\
\text { symbols) }\end{array}$ & $\begin{array}{l}\text { Horizon (FAO } \\
\text { symbols) }\end{array}$ & $\begin{array}{l}\text { Depth, } \\
\text { cm }\end{array}$ & Morphological description \\
\hline $\mathrm{AU}$ & A & $0-7$ & $\begin{array}{l}\text { Postlithogenic dark-humus horizon, dark gray-brown, moist, soft, loose, medium loam texture, gran- } \\
\text { ular-subangular blocky structure, abundant roots (of trees and grasses), no visible effervescence, } \\
\text { wavy boundary, distinct transition by color and density }\end{array}$ \\
\hline TUR (AY, TCH) & $\mathrm{Au}, \mathrm{c}$ & $7-13$ & $\begin{array}{l}\text { Turbated humus horizon with additions of technogenic material, yellowish-brownish gray, slightly } \\
\text { damp, denser than above, medium loam, subangular blocky, hard, contains blackish purple Mn nod- } \\
\text { ules up to } 2 \mathrm{~mm} \text { in diameter, many roots of grasses }(\mathrm{d}<1 \mathrm{~mm} \text { ) and trees (up to } 1.5 \mathrm{~cm} \text { thick), rare } \\
\text { artefacts, wavy boundary, distinct transition by color }\end{array}$ \\
\hline EL & Ec & $13-38 / 42$ & $\begin{array}{l}\text { From pale gray to whitish, slightly damp, dense, medium loam, platy-subangular blocky, many large } \\
\text { pores, many roots, occasional worm channels, Fe-Mn concentrations including dense nodules in- } \\
\text { creasingly abundant with depth, wavy boundary, distinct transition by color and density }\end{array}$ \\
\hline BEL & EBt & $38 / 42-51$ & $\begin{array}{l}\text { Predominantly ochric-yellow, with whitish faces of structural peds, very dense, medium loam, platy- } \\
\text { angular blocky, moderately hard, very porous, many Fe nodules including large ones, irregular } \\
\text { (tonguing) boundary, distinct transition }\end{array}$ \\
\hline BT & $\mathrm{Bt}$ & $51-80$ & $\begin{array}{l}\text { Brown with whitish mottles, fresh, dense, clay loam, coarse subangular blocky, easily breaks when } \\
\text { rubbed between fingers and thumb, with clay coatings on ped faces }\end{array}$ \\
\hline
\end{tabular}

Table 4

The morphological description of urbostratozem (Urbic Technosol) underlain by mantle loam. Pit 2

\begin{tabular}{|c|c|c|c|}
\hline $\begin{array}{l}\text { Horizon } \\
\text { (Russian } \\
\text { symbols) }\end{array}$ & $\begin{array}{l}\text { Horizon (FAO } \\
\text { symbols) }\end{array}$ & $\begin{array}{l}\text { Depth, } \\
\mathrm{cm}\end{array}$ & Morphological description \\
\hline URrz & A & $0-3$ & Sod \\
\hline UR1 & Au1 & $3-12$ & $\begin{array}{l}\text { Abundant roots, uniform color (brownish gray), loose, well-developed crumb structure, soft, many } \\
\text { worm channels, occasional artefacts ( }<10 \% \text { of a total volume), no visible effervescence, smooth } \\
\text { boundary, distinct transition }\end{array}$ \\
\hline UR2 & $\mathrm{Au} 2$ & $12-23 / 25$ & $\begin{array}{l}\text { Lighter-colored than above (pale brown background with dark mottles along vertically oriented } \\
\text { worm channels), structure coarser than above, crumb peds have more distinct shapes and horizon- } \\
\text { tal orientation, occasional artefacts ( }<10 \% \text { of a total volume), wavy boundary, distinct transition }\end{array}$ \\
\hline TCH1 & $\mathrm{Cu} 1$ & $25-40$ & $\begin{array}{l}\text { Alternating layers and lenses with high }(>20 \%) \text { contents of building waste and loose soil-parent } \\
\text { materials of varied texture, occasional sand lenses, irregular color (ochric-brown background with } \\
\text { gray-brown lenses), moist, weakly developed subangular blocky structure, moderately hard, frag- } \\
\text { mented smooth boundary, sharp transition }\end{array}$ \\
\hline $\mathrm{TCH} 2$ & $\mathrm{Au}$ & $40-53 / 56$ & $\begin{array}{l}\text { Grayish brown with brownish pale-ochric mottles, loam with numerous loamy sand layers, moist, } \\
\text { frequent ( } 30-40 \%) \text { inclusions of building waste (fiberglass and stones), the lower boundary is marked } \\
\text { by black coal layer ( } 50-53 \mathrm{~cm} \text { ) disintegrating in situ }\end{array}$ \\
\hline [BCg] & $\mathrm{BCb}, \mathrm{g}$ & $53 / 56-100$ & $\begin{array}{l}\text { Natural transitional layer between illuvial horizon and parent material of Albic Retisol, ochric brown } \\
\text { with pale hues on ped faces, occasional small black Fe-Mn nodules ( } d<1 \mathrm{~mm} \text { ), dense, moist, many } \\
\text { large pores, prismatic structure becoming coarser with depth, thin bluish films on ped faces }\end{array}$ \\
\hline
\end{tabular}

In sum, deep soil profiles of pits 1, 2 and 3 were characterized by increasing proportions of clay fractions with depth, the presence of sand fractions in many upper horizons, frequent occurrence of layered and platy structural features in upper and middle horizons, with transition to angular blocky and prismatic structures in lower horizons similar to those in natural soils.

Pit 4. Located in the Botanical Garden of the LMSU Faculty of Biology, within a plot under cultural plants. Soil profile is described in Table 6 . This profile represents a combination of a thick cultivated layer and underlying technogenic materials deposited during the period of the LMSU campus construction. It was defined as technogenic agrozem. According to the WRB (2015), it was classified as Phaeozem due to an insufficient content of artefacts.

Pit 5. Located within the inner yard (small courtyard) of the LMSU Medical Center building, under predominantly ground elder (Aegopodium podagraria L.), beneath a canopy of maple trees (Acer negundo and Acer platanoídes). Soil profile is described in Table 7. This profile does not have any features of synlithogenesis. The humus horizon has been formed on the soil 
Table 5

The morphological description of deep urbostratozem (Urbic Technosol). Pit3

\begin{tabular}{|c|c|c|c|}
\hline $\begin{array}{l}\text { Horizon } \\
\text { (Russian } \\
\text { symbols) }\end{array}$ & $\begin{array}{l}\text { Horizon } \\
\text { (FAO } \\
\text { symbols) }\end{array}$ & $\begin{array}{l}\text { Depth, } \\
\mathrm{cm}\end{array}$ & Morphological description \\
\hline URrat & $1 \mathrm{Au}, \mathrm{k}$ & $0-4 / 5$ & $\begin{array}{l}\text { Dark gray, moist, glittering grains of primary minerals free from coatings, occasional coprolites, light loam, } \\
\text { moderately developed platy-subangular blocky structure, few roots (new substrate not occupied by tree } \\
\text { roots), strong visible effervescence with } 10 \% \mathrm{HCl} \text {, wavy boundary, abrupt transition by the number of } \\
\text { inclusions }\end{array}$ \\
\hline UR2 & $1 \mathrm{Au}, \mathrm{k} 2$ & $5-38$ & $\begin{array}{l}\text { Brownish gray, fresh to slightly moist, moist along root channels, solid inclusions (lime mortar, brick, glass, } \\
\text { charcoal, etc.) content of about } 40 \% \text {, fine earth has light loam texture, occasional small lenses of yellow } \\
\text { sand, weakly structured into small subangular blocks with a horizontal orientation, soft consistency, strong } \\
\text { visible effervescence with } 10 \% \mathrm{HCl} \text { throughout the horizon, wavy boundary, distinct transition by structure } \\
\text { and by numbers of inclusions and roots }\end{array}$ \\
\hline UR3 & $1 \mathrm{Au}, \mathrm{k} 3$ & $38-83$ & $\begin{array}{l}\text { Brownish gray, fresh, moderately developed structure with subangular blocky and prismatic peds of a ver- } \\
\text { tical orientation, peds are moderately hard, 'beads'-like accumulations of peds within root zones, medium } \\
\text { loam that seems lighter due to the presence of coarse inclusions (15-20\%), strong effervescence through- } \\
\text { out, occasional worm channels, rare roots, wavy boundary, diffuse transition }\end{array}$ \\
\hline UR4 & $1 \mathrm{Au}, \mathrm{k} 4$ & $83-120$ & $\begin{array}{l}\text { Brownish gray, fresh, light loam, moderately developed structure, mostly medium-fine subangular blocky } \\
\text { peds that tend to divide into horizontal sub-units, peds are moderately hard, occasional worm channels, } \\
\text { rare small and large roots, solid inclusions (brick, lime mortar, ceramics, charcoal and bones) have a total } \\
\text { content of } 20-25 \% \text {, strong effervescence with } 10 \% \mathrm{HCl} \text { throughout the horizon, almost smooth boundary } \\
\text { with occasional pockets, sharp transition }\end{array}$ \\
\hline TCH1 & $1 \mathrm{C} 1$ & $120-127$ & $\begin{array}{l}\text { Yellowish lenses (pockets) of loose carbonate material occasionally crossing the boundary with the above } \\
\text { horizon, fresh to slightly moist, layered platy structure, occasional ochric-brown half-decomposed plant } \\
\text { residues, charcoal particles ( } 3-5 \mathrm{~mm} \text { ) and small Fe-Mn 'ortstein' concretions, extremely strong efferves- } \\
\text { cence throughout, sharp transition }\end{array}$ \\
\hline UR5 & $1 \mathrm{Ab}, \mathrm{k} 5$ & $127-136$ & Dark gray, urbic pedogenic horizon, $10 \%$ inclusions, weak visible effervescence with $10 \% \mathrm{HCl}$ \\
\hline TCH 2 & $1 \mathrm{C} 2$ & $136-142 / 150$ & $\begin{array}{l}\text { Dense layer of carbonate material, without recent traces of earthworm activity, but with singular roots, } \\
\text { smooth boundary }\end{array}$ \\
\hline UR6 & $1 \mathrm{Ab}, \mathrm{k} 6$ & $142 / 150-162$ & Almost black, urbic pedogenic horizon, $10 \%$ inclusions, visible effervescence with $10 \% \mathrm{HCl}$ \\
\hline TCH3 & $1 \mathrm{C} 3$ & $162-172 / 175$ & Layer of humified material with charcoal inclusions in its upper part, smooth boundary \\
\hline TCH4 & $1 \mathrm{Cc} 4$ & 172/175-185 & $\begin{array}{l}\text { Dense layer of carbonate material, with horizontally oriented pores, occasional 'ortstein' concretions, iron } \\
\text { pedofeatures within pores, iron concentrations and films, smooth boundary }\end{array}$ \\
\hline TCH5 & $1 \mathrm{C} 5$ & $185-190$ & Dense layer of carbonate material with a sub-layer of charcoal particles along the lower boundary \\
\hline [P1] & 2Ab,p1 & $190-210 / 218$ & Brownish gray, plough layer, layered platy structure, inclusions have a visible effervescence with $10 \% \mathrm{HCl}$ \\
\hline [P2] & $2 \mathrm{Ab}, \mathrm{p} 2$ & $210 / 218-225 / 233$ & $\begin{array}{l}\text { Lighter than the previous one, plough layer, layered platy structure, inclusions have a visible effervescence } \\
\text { with } 10 \% \mathrm{HCl}\end{array}$ \\
\hline [EL] & $2 \mathrm{~Eb}$ & $225 / 233-240 / 248$ & Pinkish white, eluvial horizon, inclusions have an audible effervescence with $10 \% \mathrm{HCl}$ \\
\hline [BT] & 2Btb & & Dark brown to brown, illuvial horizon, clay loam, angular blocky structure, non-effervescent \\
\hline [BD] & $3 \mathrm{BCb}$ & & $\begin{array}{l}\text { Reddish yellow, structureless material consisting of finely-dispersed carbonates, impregnated with ferru- } \\
\text { ginous compounds }\end{array}$ \\
\hline
\end{tabular}

Table 6

The morphological description of technogenic agrozem (Phaeozem). Pit 4

\begin{tabular}{|c|c|c|c|}
\hline $\begin{array}{l}\text { Horizon } \\
\text { (Russian } \\
\text { symbols) }\end{array}$ & $\begin{array}{l}\text { Horizon } \\
\text { (FAO } \\
\text { symbols) }\end{array}$ & $\begin{array}{l}\text { Depth, } \\
\mathrm{cm}\end{array}$ & Morphological description \\
\hline P1 & Ap & $0-20$ & $\begin{array}{l}\text { Uniform dark gray color, fresh, crumb structure, light loam, porous, slightly compacted, contains organic residues } \\
\text { (including many dead roots) that are decomposed to different degrees, generally smooth boundary with occa- } \\
\text { sional streaks along worm channels, abrupt transition by color, non-effervescent }\end{array}$ \\
\hline P2 & Ap,u & $20-35$ & $\begin{array}{l}\text { Irregular color (pale brown background with dark gray streaks along worm channels), moist, subangular blocky } \\
\text { structure, light loam, porous, slightly compacted, contains organic residues (including many dead roots) that are } \\
\text { decomposed to different degrees, occasional mole channels, rare inclusions of stones, non-effervescent, slightly } \\
\text { wavy boundary, sharp transition }\end{array}$ \\
\hline $\mathrm{TCH}$ & $\mathrm{Cu}$ & $35-60$ & $\begin{array}{l}\text { Uniform pale brown color, moist, from fine subangular blocky to coarse lumpy structure, medium loam, inclu- } \\
\text { sions of sand, gravel, brick fragments and glass ( } 20 \% \text { in total), inclusions have an audible effervescence, dense, } \\
\text { contains organic residues (dead roots) that are decomposed to different degrees }\end{array}$ \\
\hline
\end{tabular}


Table 7

The morphological description of gray-humus soil (Urbic Technosol). Pit 5

\begin{tabular}{|c|c|c|c|}
\hline $\begin{array}{l}\text { Horizon } \\
\text { (Russian } \\
\text { symbols) }\end{array}$ & $\begin{array}{l}\text { Horizon } \\
\text { (FAO } \\
\text { symbols) }\end{array}$ & $\begin{array}{l}\text { Depth, } \\
\mathrm{cm}\end{array}$ & Morphological description \\
\hline AU & $\mathrm{Au}$ & $0-10$ & $\begin{array}{l}\text { Uniform pale brownish gray color, moist, loose, crumb structure, light loam, occasional worm channels, many } \\
\text { roots, inclusions of concrete and asphalt fragments, stones, nails and metal rods, no visible effervescence with } \\
10 \% \mathrm{HCl} \text {, wavy boundary, distinct transition by color }\end{array}$ \\
\hline ATCH & Acu,k & 20-35 & $\begin{array}{l}\text { Heterogeneous color (pale gray background with orange-brown mottles), moist, crumb structure, medium loam, } \\
\text { slightly compacted, occasional roots, worm channels, inclusions (total content }>20 \% \text { ) of man-made materials } \\
\text { (broken glass, fragments of stone and metal constrictions), visible effervescence with } 10 \% \mathrm{HCl} \text {, smooth boundary, } \\
\text { sharp transition by the number of inclusions }\end{array}$ \\
\hline $\mathrm{TCH}$ & $\mathrm{Cu}, \mathrm{k}$ & $25-55$ & $\begin{array}{l}\text { Composed predominantly }(70 \%) \text { of solid fragments of building waste of different sizes, mixed with fine earth, } \\
\text { strong effervescence with } 10 \% \mathrm{HCl}\end{array}$ \\
\hline
\end{tabular}

Table 8

The morphological description of gray-humus soil (Urbic Technosol). Pit 6

\begin{tabular}{llll}
\hline $\begin{array}{l}\text { Horizon } \\
\text { (Russian } \\
\text { symbols) }\end{array}$ & $\begin{array}{l}\text { Horizon } \\
\text { (FAO } \\
\text { symbols) }\end{array}$ & $\begin{array}{l}\text { Depth, } \\
\mathrm{cm}\end{array}$ & Morphological description \\
\hline $\mathrm{AY}$ & $\mathrm{Au}$ & $0-10$ & $\begin{array}{l}\text { Uniform dark gray color, dry, crumb structure, light loam, loose, abundant roots, worm channels, inclusions (total } \\
\text { content of 10-20\%) of building waste (asphalt fragments, stones, metal nails and rods), no visible effervescence } \\
\text { with } 10 \% \mathrm{HCl} \text { slightly wavy boundary, abrupt transition by the number of inclusions and by density }\end{array}$ \\
$\mathrm{TCH}$ & $\mathrm{Cu}, \mathrm{k}$ & $10-50$ & $\begin{array}{l}\text { Composed predominantly (70\%) of solid fragments of building waste of different sizes, mixed with pale gray fine } \\
\text { earth, visible effervescence with } 10 \% \mathrm{HCl}\end{array}$ \\
\hline
\end{tabular}

remediation material, which was formerly applied onto the surface of technogenic ground. Soil-forming processes have resulted in loosening of material within the upper part of the profile.

Pit 6. Located at the same site (the inner yard of the LMSU Medical Center building) under ruderal herbaceous vegetation very closely to the asphalt pavement. Soil profile is described in Table 8.

Profiles of pits 6 and 5 were similar. Their humus horizons were only $10 \mathrm{~cm}$ thick, because the activity of soil biota in deeper layers was hindered due to a lack of fine earth in technogenic parent materials. Both profiles were classified as gray-humus soils according to the Russian system and, by the criterion of artefact contents, as Urbic Technosols according to WRB (2015).

In sum, pits 4, 5 and 6 exposed postlithogenic soils on technogenic substrates, where humus horizons with pedogenic structure were underlain by structureless or dense (with unfavorable structure) technogenic parent materials with high contents of artefacts.

\subsection{Basic physical characteristics}

Our analysis of vertical distribution patterns of bulk density (BD) values showed that they generally tended to increase with depth in soil profiles (Fig. 2a). Soddy-podzolic soil (pit 1) in the park was characterized by the lowest median value of BD in the surface horizon and a gradual increase in BD down the profile, which is a classical pattern of vertical distribution of this parameter in a non-compacted natural soil. A dispersion (variation) of values was observed throughout the profile. Urbostratozem (pit
2) of the lawn had a step-like pattern of vertical distribution of $\mathrm{BD}$, i.e., a non-uniform irregular increase in BD with depth, due to the clearly stratified arrangement of soil horizons. An older Urbostratozem (pit 3) within the mansion courtyard in the Moscow city center had very think man-made horizons and a very irregular distribution of BD values. Their decrease with depth was associated with heavier texture and prismatic-subangular blocky structure of soil horizons. Several profiles were examined in this excavation. Their structure is generally the same. A wide dispersion of BD values has been found in soils observed nearby within the mansion courtyard, but a low dispersion of BD values - in individual soil profiles (both sealed under a pavement and non-sealed) which generally characterizes a mosaic spatial pattern of functioning of city soils. Agrozem (pit 4) of the LMSU Botanical Garden was characterized by a generally steady increase in BD values with depth, apart from a local peak of BD at the $10 \mathrm{~cm}$ depth due to a dense accumulation of weeds roots.

Soils on technogenic deposits (pits 5 and 6) within the inner yard of the LMSU Medical Center building had especially high BD values in not only TCH layers, but also in humus horizons, due to high contents of stones and building waste.

The vertical distribution of saturated hydraulic conductivity $\left(\mathrm{K}_{\mathrm{s}}\right)$ values in soddy-podzolic soil (pit 1) in the LMSU park was characterized by a slight decrease in $\mathrm{K}_{\mathrm{s}}$ values with depth, but generally this soil corresponded to the class of high saturated hydraulic conductivity (Eggelsmann R. et al., 1977). In Urbostratozem (pit 2) under a lawn within the LMSU Meteorological Observatory, the upper part of profile had higher $\mathrm{K}_{\mathrm{s}}$ than the park soil (pit 1), but from the depth of $40 \mathrm{~cm}$ IR values decreased to 60 


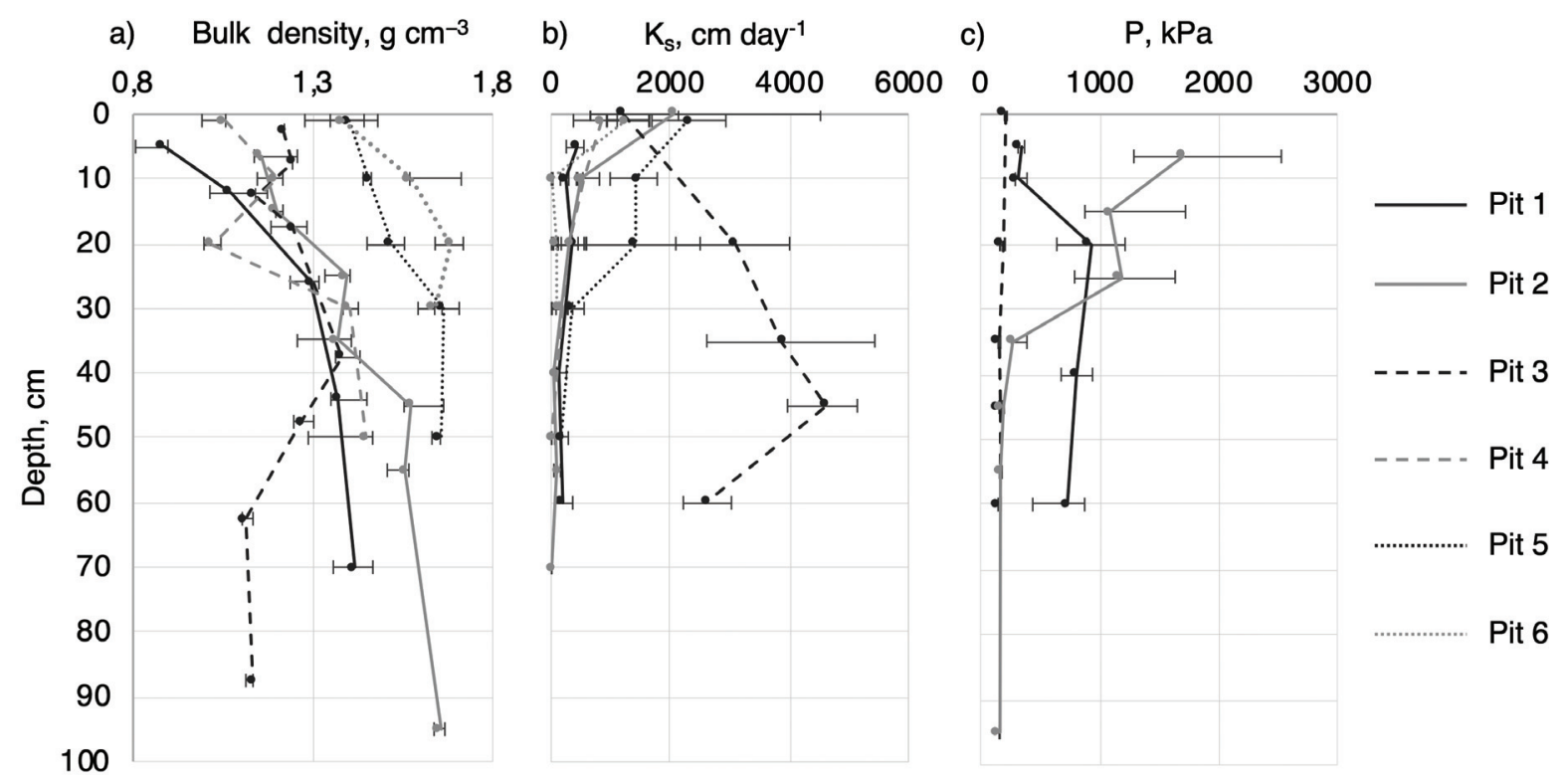

Fig. 2. Vertical distribution patterns of values of bulk density (a), infiltration rate (b) and penetration resistance (c): profile distribution with minimum and maximum values for bulk density and infiltration rate; interquartile range for penetration resistance

$\mathrm{cm} \mathrm{day}^{-1}$ ) (Fig. 2b). In the other Urbostratozem (pit 3) in the city center, $\mathrm{K}_{\mathrm{s}}$ values widely varied within each horizon, with a very rapid percolation of water observed throughout the whole profile. Very high saturated hydraulic conductivity was detected even within the UR2 $(5-38 \mathrm{~cm})$ horizon, despite the horizontal orientation of structural units, which was indicative of a presence of large pores and a significant gravitational infiltration throughout this layer.

Penetration resistance (PR) values in park soil (pit 1) gradually increased with depth and correlated with the increase in $\mathrm{BD}$, however they had different vertical distribution patterns in soils with technogenic horizons (Fig. 2c). For example, in pit 2 , an increase in artefact content down the profile was accompanied by a gradual decrease in PR. The oldest urban soil (pit 3) was characterized by low PR values throughout the profile.

\section{Discussion}

According to the urban soil systematic based on profile morphology (Hulisz et al., 2018), our studied profiles correspond to two groups: the "long-term deposition" group (deep profiles 2 and 3) and the "transport and deposition" group (pits 4, 5 and 6). Weakly changed natural profile (pit 1) can be considered as a background.

Apart from the background park soil (pit 1) and the Botanical Garden soil (pit 4) with a thick plough layer, the other studied profiles contained significant amounts of solid inclusions (domestic and building wastes), which allowed for their classification as Urbic Technosols, according to WRB classification system (IUSS Working Group WRB, 2015). However, such Urbic Technosols could be separated into different taxonomic units considering their different genesis (Prokof'eva et al., 2013, 2014).
Soil profiles exposed in pits 4, 5 and 6 consisted of postlithogenic humus horizons formed on technogenic deposits. In pits 1, 2 and 3, there were surface anthropogenic layers of different thicknesses underlain by horizons with angular and subangular blocky structure inherited from natural soils. Smooth boundaries and abrupt transitions between the anthropogenic horizons of urban soils resulted from the accretion of soil profiles due to the surface accumulation of deposits. Anthropogenic layers include in different kinds of horizons. Synlithogenic humus horizons (UR horizons) of specific city soils were characterized by increased contents of sand, probably, because of the presence of anthropogenic inclusions. UR horizons had well-developed fine-medium subangular blocky structure, often horizontally oriented. Technogenic horizons (TCH) weakly changed by pedogenesis had a less developed structure represented by coarse subangular blocks to lumpy structural units. The color of some TCH horizons was very similar to that of humus horizons due to the presence of materials enriched in soil organic carbon (TCH1 and 2 in pit2, TCH3 in pit3, TCH of 5 and 6 pits). Cementation features were observed in cases of high contents of solid inclusions and secondary carbonate impregnation (estimated by visible and strong visible effervescence with $10 \% \mathrm{HCl}$ ) in such horizons. Horizons UR and AU were morphologically very similar, except that UR horizons had stratification features associated with an irregular particle-size distribution, abundance of inclusions and a greater thickness.

A comparative analysis of morphological and physical characteristics was conducted for the four groups of diagnostic horizons of soils (see Table 2). Physical properties were analyzed using statistical parameters (mean, median, quarter and dispersion) calculated for each group of horizons (Fig. 3).

Bulk density (BD) is one of the fundamental characteristics of soil, as it predetermines possibilities for optimizing the balance of soil phases and it is necessary for calculations of stocks of 
soil nutrients and pollutants. BD values strongly depend on particle-size distribution and organic matter content (Logsdon et al., 2017; Sünal et al., 2017). Urbic horizons (UR) had relatively low BD values (median of $1.22 \mathrm{~g} \mathrm{~cm}^{-3}$ ), significantly different from those in other groups of horizons. In this case, the distribution of BD values was close to normal, with almost coinciding median and mean values and with a minimal dispersion. Technogenic layers (TCH) were distinguished by very high BD values (median of $1.5 \mathrm{~g} \mathrm{~cm}^{-3}$ ), which in some samples were even higher than BD of natural soil horizons, with strong deviations from normal distribution. Postlithogenic humus horizons also had high BD values (median of $1.36 \mathrm{~g} \mathrm{~cm}^{-3}$ ), which was generally expected in non-cultivated soils under grass vegetation (Schwartz and Smith, 2016.) Many researchers have noted the development of compacted layers under grasslands and lawns, which negatively affect the permeability of soils, the growth of root systems and the activity of soil biota (Hamilton, and Waddington, 1999; Matthieu, 2001; Belobrov and Zamotaev, 2007; Pouyat,et al., 2007; Devigne, et al., 2016). The study on physical properties of soils under different types of land use (forests, pastures and lawns of urban parks and private holdings) has shown a significantly greater compaction of soils under grasslands as compared to that of woodland soils (Price et al., 2010).

Pouyat et al. (2007) have reported a coincidence of median and mean values of BD in soils of Baltimor, USA, where median values were similar to those in our urbic horizons. They have concluded that a very wide variability of many characteristics including BD makes it impossible to define a typical city soil. In our opinion, the BD analysis is a very promising tool for urban soil diagnostics, provided that more data on densities of different type horizons will be accumulated in the near future.

Saturated hydraulic conductivity $\left(\mathrm{K}_{\mathrm{s}}\right)$ is, on the one hand, a very complex and widely variable characteristic and, on the other hand, a clear indication of probabilities for waterlogging or desiccation within each specific soil profile. Different distribution of values was observed with saturated hydraulic conductivity (Fig. 3b), i.e., there was a wide dispersion of $\mathrm{K}_{\mathrm{s}}$ values within UR horizons that had the minimal dispersion of BD values. These UR horizons, with mostly loose consistency and subangular blocky structure, had high $\mathrm{K}_{\mathrm{s}}$ values $(2566 \mathrm{~cm}$ day $^{-1}$ ), which were significantly different from $\mathrm{K}_{\mathrm{s}}$ values in other groups of horizons. This was an expected result, because water percolation through a layer was primarily determined by high (more than $40 \%$ of the total volume) contents of anthropogenic inclusions, irrespective of the degree of aggregation (structure development) in fine earth. There were lower absolute values and narrower dispersion of saturated hydraulic conductivity in other types of horizons, in particular, in lower horizons of natural soils with angular blocky and coarse subangular blocky - angular blocky structures. Many researchers pay great attention to the influence of solid inclusions on the city's soil. But they mainly concern the effect on chemical and physical-chemical properties (Wessolek et al. 2011; Nehls et al., 2013; Howard and Orlicki, 2016; Greinert and Kostecki, 2019).

Most soils (pits 2, 4, 5 and 6) within the LMSU campus were formed on technogenic materials deposited 70 years ago and, therefore, had very similar patterns of vertical distribution of

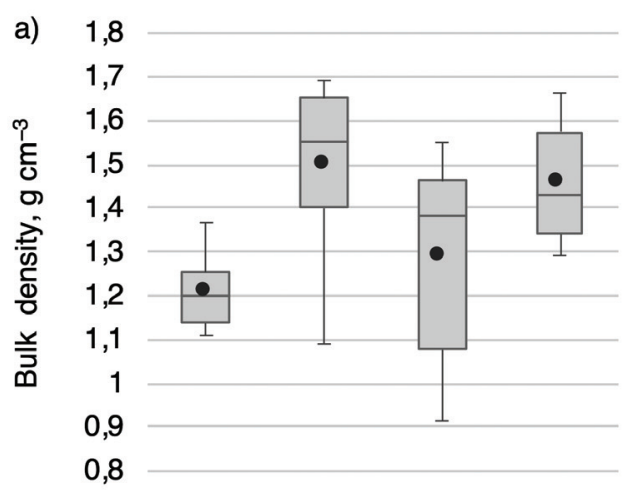

b) 6000

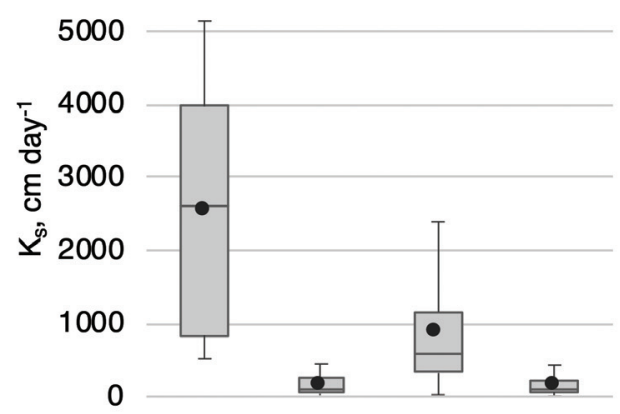

c) 1400

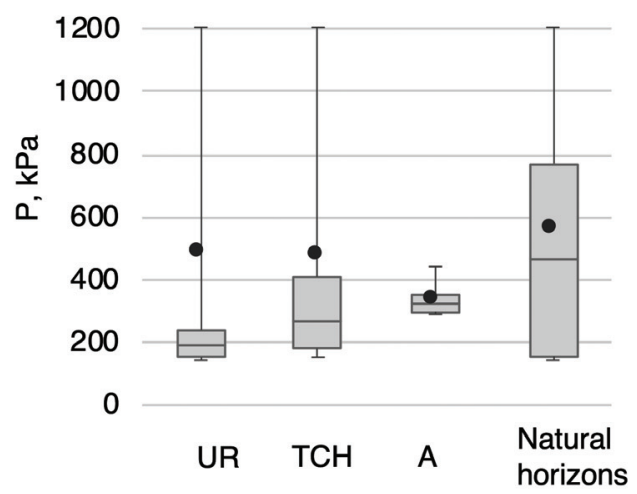

Fig. 3. Bulk density (a), infiltration rate (b) and penetration resistance (c) of soil horizons: median, mean and quarter values and dispersion

$\mathrm{K}_{\mathrm{s}}$ values, although their absolute BD values were different (Fig. 2a). Their infiltration rates (IR) were not very high, in spite of significant volumes of anthropogenic inclusions. On the basis of comparing $\mathrm{K}_{\mathrm{s}}$ values in pits 2, 4, 5 and 6 with the high $\mathrm{K}_{\mathrm{s}}$ in the ancient urban soil (pit 3) in the city center, we can suggest either that a long period of time was required for the development of the pore system for water percolation through soil horizons with high contents of artefacts or a more gradual accumulation of substrates that in pit 3 accounted for its high $\mathrm{K}_{\mathrm{s}}$.

The mean values of BD for UR, AU and TCH groups of soil horizons was $1.21,1.29$ and $1.5 \mathrm{~g} \mathrm{~cm}^{-3}$, mean values of $\mathrm{K}_{\mathrm{s}}-2566$, 873 and $158 \mathrm{~cm}$ day $^{-1}$ respectively. Apparently, heterogeneity of profiles of specific urban soils - Urbostratozems - in terms of BD and IR parameters can be regarded as their typical characteristic. Cadenasso and Pickett (2008) write about heterogeneity as a basic property of the urban environment. 
Penetration resistance characterizes both porosity and cohesion of the solid phase of soils, i.e., the resistance of the mass of soil particles to penetration by different tools (Sinnett et al., 2008; Zadorozhnaya, 2018.). Values of PR were most varied in natural soil horizons, which was not surprising, because such horizons had largest structural units (peds) and the cone-shaped measuring device was driven through not only voids between peds, but also highly resistant hard surfaces of peds. Humus horizons with mostly crumb structure were distinguished by a minimal dispersion and almost normal distribution of PR values. Urbic horizons, despite their peds had uniform sizes, were characterized by a wide dispersion of PR values, which was due to the diversity of ped shapes (crumbs, plates, subangular blocks, etc.). It should be mentioned that in technogenic horizons PR values were determined only within fine earth concentration zones. Clearly, anthropogenic inclusions had very variable PR, up to zero values.

Charzyński et al. (2013), following the substrate approach for international classification of soils on technogenic materials, have suggested to extend the list of qualifiers (for different types of substrates and land use) for the Reference Group of Technosols with the purpose of their better description, as Technosols are extremely heterogeneous soils. In our opinion, such extension is not always advisable, as it does not help to identify soil evolution trends and does not always help to predict the influence of different substrates on properties and ecological functions of soils. We believe that the genetic approach to urban soil classification should be preferred for distinguishing taxonomic units by truly soil properties.

Taking into account general differences in genesis of urban soil profiles, we focused our attention on certain types of diagnostic horizons (UR, AU and TCH). Our study on physical properties of such horizons opens new perspectives for diagnostics of urban soils in Moscow. We believe that more data on physical properties of different types of horizons should be accumulated for making it possible to establish typical values of physical characteristics of such horizons. Of course, it is very promising to determine the quantitative parameters of soils physical properties to develop ranges of their variation and criteria for their evaluation. This can help us to understand the optimal values of this parameters for the functioning of urban soils.

\section{Conclusions}

As a result of our comparative study on urban soils in the city of Moscow, it was shown that soil horizons and layers had certain characteristics based on combinations of interdependent morphological and physical properties. New data on urban soils formed on parent materials of silty loam texture were obtained. Bulk density and infiltration rate values in the studied soils were comparable with those in loamy soils in other cities of the world.

An abundance of solid inclusions of building rubble and domestic waste in the studied urban soils was a key factor, which predetermined both their morphological and physical characteristics, in particular, their BD and IR. Profile and intra- -horizon distribution patterns of these properties in the studied soils were more heterogenous than those in natural soils.

It was established that, in cases of equally high contents of solid inclusions, IR values in technogenic horizons with high BDs were significantly lower than those in urbic horizons. However, it was noted that high values of bulk density were not always indicative of low infiltration rates in soils of the city, e.g., some humus horizons can have high densities.

Different types of diagnostic horizons distinguished on the basis of their morphological features and genesis had different physical properties, which confirmed that physical properties were worth considering as additional classification criteria for urban soils. It was demonstrated that bulk density and infiltration rate were very informative parameters, as they allowed for a statistically reliable differentiation between synlithogenic urbic humus horizons (UR), postlithogenic dark humus horizons (AU) and layers of technogenic materials (TCH) non-affected by pedogenesis. In order to include urban soils into the Soil Classification of Russia, it is important to confirm the pedogenic origin of the urbic horizon and its difference from postlithogenic humus horizons and technohenic ground layers. In the WRB system, a consideration of BD and IF parameters within a 1-m soil thickness can allow for dividing Urbic Technosols into two groups of soils with different conditions for plant growth. The latter can be achieved either by replacing the Urbic qualifier by two other qualifiers or by introducing new kinds of supplementary qualifiers. Penetration resistance was shown to be a less informative parameter in this study.

The present study, where median values of basic physical parameters were obtained for UR, AU and TCH horizons, can be considered as the first step in the development of new quantitative criteria for urban soil diagnostics.

\section{Acknowledgments}

Studies was supported by Russian Foundation for Basic Research: Project № 19-04-01298 "Fundamental structural and functional characteristics of urban soils in different climatic zones" (field work, collection of samples, determination of basic physical properties, and their interpretation (pits 1,2,3)), project № 19-29-05252 "Soil constructions: fundamental physical and biological aspects of their creation, functioning and evolution in a humid and arid climate" (field work, collection of samples, determination of basic physical properties (pits 4,5,6)). The authors are thankful to A.V. Dolgikh (the Institute of Geography of the Russian Academy of Sciences) and S. V. Malykh and D. Yu. Davydov (the Metropolitan archaeological Bureau, Moscow) for organizing the field work at the archaeological site within the territory of the Pushkin State Museum of Fine Arts.

\section{References}

Blanchart, A., Séré, G., Johan, C., Gilles, W., Stas M., Consalčs, J.N., Morel, J.L., Schwartz, C., 2018. Towards an operational methodology to optimize ecosystem services provided by urban soils. Landscape and Urban Planning, 176, 1-9. https://doi.org/10.1016/j.landurbplan.2018.03.019 
Belobrov, V.P. and Zamotaev, I.V., 2007. Soils, grounds and green-lawns of sport and technical constructions. GEOS, Moscow. (in Russian)

Beven, K., Robert, E., 2004. Horton's perceptual model of infiltration processes. Hydrological Processes 18, 3447-3460. https://doi.org/10.1002/ hyp. 5740

Cadenasso, M.L., and Pickett, S.T.A., 2008. Urban principles for ecological landscape design and management: Scientific fundamentals. Cities and the Environment, 1(2): article 4, 16pp. http://escholarship.bc.edu/ cate/vol1/iss2/4 http://doi.org/10.15365/cate.1242008

Charzyński, P., Bednarek, R., Greinert, A., Hulisz, P., Uzarowicz, Ł., 2013. Classification of technogenic soils according to WRB system in the light of Polish - experiences. Soil Science Annual 64(4), 145-150. https://doi.org/10.2478/ssa-2013-0023

Craul, P.J., 1992. Urban soils in landscape design. John Wiley \&Sons, NewYork.

Devigne, C., Mouchon, P., Vanhee, B., 2016. Impact of soil compaction on soil biodiversity - does it matter in urban context?. Urban Ecosystems 19, 1163-1178. https://doi.org/10.1007/s11252-016-0547-z

Dornauf, C. and Burghardt, W. (2000) The effects of biopores of permeability and storm water infiltration - case study of the construction of a school. [In:] Burghardt, W. and Dornauf, C. (Eds.) Proceedings of First International Conference SUITMA. Essen, 2, 459-464.

Eggelsmann, R., et al., 1977. Bodenkundliche-hydrologische feldmethoden und deren aussagewert fuer wasserwirtschaft, bodenkultur und landschalftspflege in niederungsgebieten.

Ferreira, C.S.S., Rory P.D. W., Ferreira A.J.D., 2018. Degradation in urban areas. Current Opinion in Environmental Science \& Health, 5(10), 19-25. https://doi.org/10.1016/j.coesh.2018.04.001

Greinert, A., Kostecki, J., 2019. Anthropogenic Materials as Bedrock of Urban Technosols. [In:] Vasenev, V., Dovletyarova, E., Cheng, Zh., Prokof'eva, T., Morel, J.-L., Ananyeva, N. (Eds.), Urbanization: Challenge and Opportunity for Soil Functions and Ecosystem Services Proceedings of the 9th SUITMA Congress. Springer International Publishing AG, part of Springer Nature, 11-20. https://doi.org/10.1007/978-3-319-89602-1_3

Guidelines for Soil Description, 2006. Food and Agriculture Organization of the United Nations, Rome.

Hamilton, G.W., and Waddington, D.V., 1999. Infiltration rates on residential lawns in central Pennsylvania. Journal of soil and water conservation 54(3), 564-568.

Howard, J.L., Orlicki, K.M., 2016. Composition, micromorphology and distribution of microartefacts in anthropogenic soils, Detroit, Michigan, USA. Catena 138 (3) 103-116. https://doi.org/10.1016/ j.catena.2015.11.016

Hulisz, P., Charzyński, P., Greinert, A., 2018. Urban soil resources of medium-sized cities in Poland: a comparative case study of Torun and Zielona Góra. Journal of Soils and Sediments 18, 358-372. https://doi. org/10.1007/s11368-016-1596-X

IUSS Working Group WRB, 2015. World Reference Base for soil resources 2014, update 2015. International soil classification system for naming soils and creating legends for soil maps. World soil resources reports no. 106. FAO, Rome.

Jackson, R., Thompson, J., Kolka, R., 2014. Wetland soils, hydrology, and geomorphology. [In:] Batzer, D., Sharitz, R. (Eds.) Ecology of freshwater and estuarine wetlands. Berkeley, CA: University of California Press, 23-60. Chapter 2.

Lehmann, A., Stahr, K., 2007. Nature and Significance of Anthropogenic Urban Soils. Journal of Soils \& Sediments 7 (4), 247-260. https://doi. org/10.1065/jss2007.06.235

Logsdon, S.D., Sauer, P.A., Shipitalo, M.J., 2017. Compost improves urban soil and water quality. Journal of Water Resource and Protection, 9(4), 345-357. https://doi.org/10.4236/jwarp.2017.94023

Matthieu, D.E., Bowman, D.C., Thapa, B.B., Cassel, D.K., Rufty, T.W., 2001 Turfgrass root response to subsurface soil compaction. Communications in soil science and plant analysis 42(22), 2813-2823. https://doi. org/10.1080/00103624.2011.622826
McKenzie, N., Coughlan, K., Cresswell, H., 2002. Soil physical measurement and interpretation for land evaluation. Csiro Publishing.

Mullins, C.E., 1991. Physical properties of soils in urban areas. [In:] Bullock P., Gregory P.J. (Eds.), Soils in the urban environments. Blackwell Scientific publications, Oxford, 87-118. https://doi.org/10.1002/97814 44310603.ch6

Nehls, T., Rokia, S., Mekiffer, B., Schwartz, C., Wessolek, G., 2013. Contribution of bricks to urban soil properties. Journal of Soils and Sediments 13, 575-584. https://doi.org/10.1007/s11368-012-0559-0

Nero, B.F. and Anning, A.K., 2018. Variations in soil characteristics among urban green spaces in Kumasi, Ghana. Environmental Earth Sciences 77, 317. https://doi.org/10.1007/s12665-018-7441-3

Nizovtsev, V.A., 2004. Landscape conditions and their influence on the formation of the natural resource management system in the territory of modern Moscow. [In:] Culture of Medieval Moscow: Historical landscapes (3 volume). Belyaev L.A., Makarova T.A. and Chernov S.Z. (Eds.). Moscow, Nauka (in Russian)

Pouyat, R.V., Yesilonis, I D., Russell-Anelli, J., Neerchal, N.K., 2007. Soil chemical and physical properties that differentiate urban land-use and cover types. Soil Science Society of America Journal. 71 (3), 1010 1019. https://doi.org/10.2136/sssaj2006.0164

Price, K., Jackson, C.R., Parker, A.J., 2010. Variation of surficial soil hydraulic properties across land uses in the southern Blue Ridge Mountains, North Carolina, USA. Journal of hydrology, 383(3-4), 256-268. https://doi.org/10.1016/j.jhydrol.2009.12.041

Prokof'eva, T.V., Gerasimova, M.I., Bezuglova, O.S., Bakhmatova, K.A., Gol'eva, A.A., Gorbov, S.N., Zharikova, E.A., Matinyan, N.N., Nakvasina, E.N., Sivtseva, N.E., 2014. Inclusion of soils and soil-like bodies of urban territories into the Russian soil classification system. Eurasian Soil Science 47(10), 959-967. https://doi.org/10.1134/ S1064229314100093

Prokofyeva, T.V., Martynenko, I.A., Ivannikov, F.A., 2011. Classification of Moscow soils and parent materials and its possible inclusion in the classification system of Russian soils. Eurasian Soil Science 44(5), 561-571. https://doi.org/10.1134/S1064229311050127

Prokofeva, T., Gerasimova, M., Lebedeva, I., Martynenko, I., 2013. An attempt of integrating the systematic of urban soils into the new Russian soil classification system. Soil Science Annual. 64 (1), 24-29. https://doi.org/10.2478/ssa-2013-0005

Prokof'eva, T., Martynenko, I., 2017. Urban soil surveys: The case of Moscow, Russia. [In:] Levin M.J. et al. (Eds.), Soils within cities. Global approaches to their sustainable management - composition, properties, and functions of soils of the urban environment. Schweizerbart Science Publishers (Stuttgart, Germany) - Catena Soil Science, 129-139.

Scharenbroch, B.C., Lloyd, J.E., Johnson-Maynard, J.L., 2005. Distinguishing urban soils with physical, chemical, and biological properties. Pedobiologia 49(4) 283-296. https://doi.org/10.1016/j.pedobi.2004.12.002

Schwartz, S., S., Smith, B., 2016. Restoring hydrologic function in urban landscapes with suburban subsoiling. Journal of Hydrology 543(12), 770-781. https://doi.org/10.1016/j.jhydrol.2016.10.051

Shein, E.V., Karapachevskii, L.O. (Eds.), 2007. Soil Physics: Theory and Methods. Grif and K, Moscow. (in Russian)

Short, J.R., Fanning, D.S., Foss, J.E., Patterson, J.C., 1986. Soils of the Mall in Washington, DC: I. Statistical summary of properties. Soil Science Society of America Journal. 50, 699-705. http://dx.doi.org/10.2136/sss aj1986.03615995005000030030x

Shishov, L.L., Tonkonogov, V.D., Lebedeva, I.I., Gerasimova, M.I., 2004. Classification and Diagnostics of Soils of Russia. (in Russian) English version: Dobrovolski, G. (Ed.), 2001. Russian Soil Classification System. Oekumena, Smolensk.

Sinnett, D., Morgan, G., Hutchings, T.R., 2008. Soil penetration resistance and tree root development. Soil Use and Management 24(3), 273-280. https://doi.org/10.1111/j.1475-2743.2008.00164.x

Stroganova, M., Miagkova, A., Prokofieva, T., Skvortsova, I., 1998. Soils of Moscow and urban environment. PAIMS, Moscow. 
Sünal, S., Dikmen, Ü., Timur, U.P., Timur, Ö.B., Erşahin, S., 2017, Effect of Soil Bulk Density to Urban Plant in Semi-Arid Landscape. International Journal of Landscape Architecture Research (IJLAR) 1(1), 27-29.

Yang, J.L., Zhang, G.L., 2011. Water infiltration in urban soils and its effects on the quantity and quality of runoff. Journal of Soils and Sediments 11(5), 751-761. https://doi.org/10.1007/s11368-011-0356-1

Wang, P., Zheng, H., Ren, Z., Dan, Zh., Chang, Zh., Zhixia, M., Ze, T., Xingyuan, H., 2018. Effects of Urbanization, Soil Property and Vegetation Configuration on Soil Infiltration of Urban Forest in Changchun, Northeast China. Chinese Geographical Science 28, 482-494. https:// doi.org/10.1007/s11769-018-0953-7
Wessolek, G., Kluge, B., Toland, A., Nehls, T., Klingelmann, E., Rim, Y.N., Mekiffer, B., Trinks, S., 2011. Urban soils in the Vadose zone - 4.3. Soils on WWII Rubble. [In:] Endlicher, W., et al. (Eds.), Perspectives in urban ecology. Springer Verlag, Berlin-Heidelberg, 89-134. https:// doi.org/10.1007/978-3-642-17731-6_4

Zadorozhnaya, G., 2018. Spatiotemporal Dynamics of Soil Penetration Resistance of Recultivated Soil. Ekológia (Bratislava) 37(1), 82-89. https://doi.org/10.2478/eko-2018-0008

State standard of Russian Federation (GOST) 5180-84, 2005. Grounds. Methods for laboratory determination of physical characteristics. (in Russian) http://docs.cntd.ru/document/gost-5180-84 